The International Journal of Indian Psychology: Volume: 01 | Issue: 04 No. 2 | ISSN 2348-5396

\title{
A Study of Academic Anxiety of Secondary School Students With Relation To Their Gender and Religion
}

\author{
Dr. Arvindgiri K. Aparnath*
}

\begin{abstract}
:
The present study is based on Academic anxiety. The aim of the study is to find out the difference between religion and gender, regarding academic anxiety for the purpose of the study, 120 School children were chosen from different school at Kapadwanj town, Gujarat, for data collection in all 120 student, 60 being boys (30 Hindu +30 Muslim ) and 60 girls (30 Hindu +30 Muslim ).

Generally anxiety can be either a trait anxiety or a state anxiety. A trait anxiety is a stable characteristic or trait of the person. A state anxiety is one which is aroused by some temporary condition of the environment such as examination, accident, punishment, etc. Academic anxiety is a kind of state anxiety which relates to the impending danger from the environments of the academic institution including teacher, certain subjects like Mathematics, English, etc.

I have used 'Academic Anxiety Scale for children' (AASC Scåle) by Dr. A. k. Singh \& Dr. (km) A. Sen Gupta. The obtained data analyzed through Mann-Whitney ' $U$ ' test. The result shows that there was no significant difference between the Academic anxiety of Muslim boys \& girls and Hindu girls \& Muslim girls. There is more Academic anxiety in Hindu girls then Hindu boys and more Academic anxiety in Muslim boys then Hindu boys.
\end{abstract}

KEY WORD: Academic Anxiety, Gender, Religion, Boys, Girls, Hindu, Muslim.

\section{INTRODUCTION}

Today anxiety is a common phenomenon of every day life. It play a crucial role in human life because all of us are the victim of anxiety in different ways. (Goodstein and Lanyon, 1975) Generally anxity can be either a trait anxiety or a start anxity. A trat anxiety is a stable characteristic or trait of the person. A state anxiety is one which is aroused by some temporary condition of the environment such as examination, accident, punishment, etc.

*Adhyapak sahayak, Department of Psychology, Shah K .S. Arts \& V.M. Parekh Commerce College, KAPADWANJ, Dis. Kheda, Gujarat. 
Academic anxiety is a kind of state anxiety which relates to the impending danger from the environments of the academic institution including teacher, certain subjects like Mathematics, English, etc

James C. Coleman has mentioned in 1981 that $17^{\text {th }}$ Century was that of knowledge, $18^{\text {th }}$ Century was identified with the logic, $19^{\text {th }}$ Century stood for progressive and the $20^{\text {th }}$ Century was grounded upon the element of anxiety. Presently we are passing through the first decade of $21^{\text {th }}$ Centrury in split of that it same that we are living $20^{\text {th }}$ century.

Anxiety is defined by Mc Dougal (1908) as a complex emotion and is essentially a matter of alertness or watchfullness. Sinha (1966) Tiwari er al (1980) Jidal and Pande (1982) have reported that anxiety works destructively and it retards, learning and is detrimental to effective performance.

\section{OBJECTIVES:}

The objectives of this study are as follows :

1. To find out and compare the Academic anxiety of Hindu boys and Hindu girls.

2. To find out and compare the Academic anxiety of Muslim boys and Muslims girls.

3. To find out and compare the Academic anxiety of Hindu boys and Muslim boys.

4. To find out and compare the Academic anxiety of Hindu boys and Muslim girls.

5. To find out and effect of Gender and Religion on Academic anxiety.

\section{HYPOTHESIS:}

As per the consideration of the objective for the person study, we have done following hypothesis for testing:

1. HO 1 : There is no significant difference between Hindu boys and Hindu girls in relation to Academic anxiety.

2. H0 2 : There is no significant difference between Muslim boys and Muslim girls in relation to Academic anxiety.

3. HO 3 : There is no significant difference between Hindu boys and Muslim boys in relation to Academic anxiety.

4. HO 4 : There is no significant difference between Hindu girls and Muslim girls. 
The International Journal of Indian Psychology: Volume: 01 | Issue: 04 No. 2 | ISSN 2348-5396

\section{METHODOLOGY:}

\section{Population :}

According to Gilford, population consists all the situations, people and objects which have the same characteristics.

In the present study, we considered secondary school students groups, at the Kapadwanj town, Kheda District of Gujarat State.

\section{Sample:}

\section{Variables:}

"Sample means the random selection of groups from population to get information about population".

The sample for the present study was drawn from the secondary school students located in the town of Kapadwanj, Kheda District of Gujarat State. The samples consisted of 60 boys (30 Hindu +30 Muslim) and 60 girls (30 Hindu +30 Muslim).

1. Independent Variables :

2. Dependent Variables :
1. (I) Gender
(II) Religion

a. Academic Anxiety

Tools:

In the present study measure the Academic anxiety "Academic anxiety scale for children" (AASC Scale) by Dr. A.K. Singh and Dr. A. Sen Gupta was used which is very reliable in this scale.

\section{Statistical Technique:}

Mann-Whitney: ' $U$ ' test was applied to know the significant difference between Academic anxiety level of Gender and Religion Secondary school students.

\section{RESULT \& DISCUSSION:}

TABLE-1. Academic anxiety of Hindu boys and Hindu girls.

\begin{tabular}{|l|l|l|l|l|l|}
\hline Group & $\mathrm{N}$ & Rank & 'U' & Z & Level of significant \\
\hline Hindu boys & 30 & 823 & 542 & 5.35 & 0.05 \\
\hline Hindu girls & 30 & 1144 & 221 & - & \\
\hline
\end{tabular}

TABLE-2. Academic anxiety of Muslim boys and Muslim girls.

\begin{tabular}{|l|l|l|l|l|l|}
\hline Group & N & Rank & 'U' & Z & Level of significant \\
\hline Muslim boys & 30 & 682 & 683 & 0.40 & NS \\
\hline Muslim girls & 30 & 932 & 433 & - & \\
\hline
\end{tabular}


The International Journal of Indian Psychology: Volume: 01 | Issue: 04 No. 2 | ISSN 2348-5396

TABLE-3. Academic anxiety of Hindu boys and Muslim boys.

\begin{tabular}{|l|l|l|l|l|l|}
\hline Group & $\mathrm{N}$ & Rank & 'U' & Z & Level of significant \\
\hline Hindu boys & 30 & 740 & 625 & 4.10 & 0.05 \\
\hline Muslim boys & 30 & 1090 & 275 & - & \\
\hline
\end{tabular}

TABLE-4. Academic anxiety of Hindu girls Muslim girls.

\begin{tabular}{|l|l|l|l|l|l|}
\hline Group & $\mathrm{N}$ & Rank & 'U' & Z & Level of significant \\
\hline Hindu girls & 30 & 845 & 520 & 1.01 & NS \\
\hline Muslim girls & 30 & 958 & 407 & - & \\
\hline
\end{tabular}

\section{TABLE -1}

Shows Academic anxiety of Hindu boys and Hindu girls. For Hindu boys obtained rank number is 823 and Hindu girls obtained rank number is 1144. "U" for Hindu boys 542 and for Hindu girls 221 for both groups " $Z$ " value is 5.35 and its level of significant is 0.05 .

\section{TABLE -2}

Shows Academic anxiety of Muslim boys and Muslim girls. For Muslim boys obtained rank number is 682 and Muslim girls obtained rank number is 932. " $U$ " for Muslim boys 683 and for Muslim girls 433 for both groups " $Z$ " value is 0.40 and its level is not significant.

\section{TABLE -3}

Shows Academic anxiety of Hindu boys and Muslim boys. For Hindu boys obtained rank number is 740 and Muslim boys obtained rank number is 1090. "U" for Hindu boys 625 and for Muslim boys 275 for both groups " $Z$ " value is 4.10 and its level of significant is 0.05 .

\section{TABLE -4}

Shows Academic anxiety of Hindu girls and Muslim girls. For Hindu girls obtained rank number is 845 and Muslim girls obtained rank number is 958. " $U$ " for Hindu girls 520 and for Muslim girls 407 for both groups " $Z$ " value is 1.01 and its level is not significant.

\section{DISCUSSION:}

\section{TABLE No. 1:}

With reference to the hypothesis No.1 the result indicates. The Academic anxiety between Hindu boys and Hindu girls. The result show that there is a significant difference in the Academic anxiety level of Hindu girls. For the Hindu girls rank is more value. And "Z" value is significant at 0.05 level, it means level of Academic anxiety is more in Hindu girls than Hindu boys. We have concluded that reason behind, girls are different type of role like home, school and community etc. May be effect to Hindu girls Academic anxiety. So we rejected hypothesis No.1.
(C) 2014 www.ijip.in
July-September 2014
$56 \mid \mathrm{P}$ a g e 
The International Journal of Indian Psychology: Volume: 01 | Issue: 04 No. 2 | ISSN 2348-5396

\section{TABLE No.2}

With reference to the hypothesis No.2. The result show that there is no significant difference between the mean of scores of Academic anxiety of Muslim boys and Muslim girls. It can be interpreted that is no effect of sex on Academic anxiety. That's why the fact of hypothesis is accepted.

\section{TABLE No.3}

With reference to the hypothesis No.3. The result shows the Academic anxiety between Hindu boys and Muslim boys. The result shows that there is a significant difference in the Academic anxiety level of Hindu boys and Muslim boys. For the Muslim boys rank is more value and "Z" value is significant at 0.05 level it means level of Academic anxiety is more in Muslim boys than Hindu boys. We have concluded that reason behind Muslim boys are involve of your father business and lack of education awareness etc. May be effect to Muslim boys Academic anxiety. So we rejected hypothesis No.3.

\section{TABLE No.4}

With reference to the hypothesis No.4. The result shows that there is no significant difference between the mean scores of Academic anxiety of Hindu girls and Muslim girls. It can be interpreted that is no effect of Gender on Academic anxiety. That's why the fact of hypothesis is accepted.

\section{CONCLUSION:}

1. There was a significant difference between Hindu boys and Hindu girls regarding Academic anxiety. It means the level of Academic anxiety is more in Hindu girls than Hindu boys.

2. There was no significant difference between Muslim boys and Muslim girls regarding Academic anxiety.

3. There was significant difference between Hindu boys and Muslim boys regarding Academic anxiety. It means the level of Academic anxiety is more in Muslim boys than Hindu boys.

4. There was no significant difference between Hindu girls and Muslim girls regarding Academic anxiety. 
The International Journal of Indian Psychology: Volume: 01 | Issue: 04 No. 2 | ISSN 2348-5396

\section{REFERENCES:}

1. Coleman J.C. (1981) : Abnormal Psychology and Modern Life; D.B. Taraporevala Sons \& Co. Bombay (Mumbai).

2. Sheroan, A and Kalia, A.K. (2005) : A study of depression, study habits and academic anxiety of Urban and Rural Schedule Caste adolescent : Indian Journal of Community Psychology, volume -213-222.

3. Singh A.K. and Sen Gupta A(1984) : Academic Anxiety Scale for Children, National Psychology Corporation, Agra.

4. Singh, R.S. (N.D.) : Correlates of Anxiety, National Psychological Corporation, Agra.

5. Suresh C. Parekh and Dr. S.K. Dikshsit (1995) Manovaigyanik Sanshodhanoma Aankadashastriy Parikshan. 